Acta Universitatis Nicolai Copernici • Pedagogika XLI/1/2021

Nauki Humanistyczno-Społeczne • Zeszyt 453

DOI: http://dx.doi.org/10.12775/AUNC_PED.2021.012

\author{
Angelika Kalinowska \\ Uniwersytet Mikołaja Kopernika w Toruniu \\ ORCID: 0000-0001-8392-7749
}

\title{
Justyna Iskra, Waldemar Klinkosz, Trudności doświadczane przez studentów. Metoda pomiaru i możliwości pomocy,
}

Warszawa, Wydawnictwo Difin SA, 2020, ss. 166

\begin{abstract}
kres studiów to niezwykły czas dla każdego studenta. Są to początki jego dorosłości, decyzji stanowiących o przyszłości, pewnych kalkulacji, nierzadko zmiany miejsca zamieszkania, spotykania nowych ludzi, organizacja i zarządzanie własnymi środkami finansowymi. Czas zdobywania wyższego wykształcenia to nie tylko nauka - lub jak niektórzy sądzą - czas dobrej zabawy. To przede wszystkim pora wielkich zmian i niełatwych decyzji. Zmierzanie się nie tylko z nauką i egzaminami, ale także - a może przede wszystkim - z nową rzeczywistością, gdzie głównymi kierowcami pojazdu jakim jest życie są już nie rodzice, ale student, osoba wchodząca $w$ realia dorosłości. Problematyką dylematów studentów zajęli się Justyna Iska oraz Waldemar Klinkosz w publikacji pod tytułem Trudności doświadczane przez studentów. Metoda pomiaru i możliwości pomocy. Tytuł tej pozycji jest doskonałym odzwierciedleniem treści, gdyż czytelnik znajdzie tam zarówno klasyfikację i opis trudności, z jakimi borykają się studenci, ale również autorskie narzędzie do badania tychże przeciwności. Książka składa się z wprowadzenia, czterech rozdziałów i aneksów. Autorzy załączyli także autorskie narzędzie nazwane Kwestionariuszem Trudności Studenc-
\end{abstract}


kich, które może wykorzystać każda osoba związana ze środowiskiem akademickim.

Rozdział pierwszy został zatytułowany Bycie studentem z perspektywy nowych doświadczeń. Autorzy w części tej skupili się na przedstawieniu egzystencji studentów z perspektywy tych, którzy dopiero zaczynają swoją przygodę ze studiowaniem. Pierwszy rok akademicki, w ujęciu autorów, to czas zmian w każdym aspekcie życia młodego człowieka. Zauważają oni, że czas rozpoczęcia studiów przypada na okres wchodzenia w dorosłość. Etap ten jest trudny dla człowieka nie tylko ze względu na podjęcie nauki na poziomie wyższym, lecz także na ponoszeniu odpowiedzialności za własne decyzje i wybory - nierzadko te dotyczące przyszłości. Jak pisze Iskra i Klinkosz: „każdy etap edukacji stawia przed daną osobą, bez względu na to czy będzie dzieckiem, czy też osobą dorosłą, nowe zadania, które dla wielu osób staną się wyzwaniami mobilizującymi do działania lub sprawiającymi, że rezygnują z wysiłku i próby sprawdzania i rozwijania swoich możliwości i umiejętności”'. Dzieje się tak, gdy zaczynamy edukację wczesnoszkolną, ale także, kiedy następuje początek kształcenia w uczelniach wyższych. Zdaniem autorów, każda osoba, rozpoczynająca byt już nie jako maturzysta, a student ma pewne oczekiwania, plany i marzenia $\mathrm{z}$ wiązane $\mathrm{z}$ nadchodzącym „nowym”. Nową uczelnią, nowymi znajomymi, nowym etapem życia, nierzadko zamieszkaniem w nowej miejscowości, w nowym miejscu, wśród nowych ludzi. Jednych to „nowe” motywuje, wprawia wręcz w stan podniecenia, innych przeraża i wycofuje. Autorzy omawianej publikacji opierają się na tezie naukowców (m.in. Boreckiej-Biernat, Łukaszewskiego, Kramer i Hoffmann), że „[...] czas rozpoczęcia studiów to czas zmian życiowych dotyczących prawie wszystkich dziedzin życia i rozwoju człowieka” ${ }^{2}$. Jest to „[...] okres zmian o charakterze rozwojowym, społecznym, edukacyjnym oraz światopoglądowym"3. Iskra i Klinkosz wyraźnie wskazali, że zachodzące zmiany dotyczą każdego aspektu życia człowieka. Dlatego to, jak sobie z nimi poradzą zależy od

1 J. Iskra, W. Klinkosz, Trudności doświadczane przez studentów. Metoda pomiaru i możliwości pomocy, Wydawnictwo Difin, Warszawa 2020, s. 11.

2 Tamże, s. 16.

3 Tamże, s. 14. 
tego, jakim są typem studenta. Iskra ${ }^{4}$ wyróżniła takie typy jak STUDENCI SWOBODNI - którzy nie odczuwają trudności z pojawiającymi się zamianami, szybko się do nich dostosowują, są elastyczni, „nowe” sprawia im więcej radości niżeli lęku, STUDENCI SZUKAJĄCY WSPARCIA każda zmiana wywołuje u nich silny stres, brak wiary w pokonanie pojawiających się trudności, nie czują się bezpieczni, unikają kontaktu z innymi, „nowymi”, preferują kontakty interpersonalne w gronie osób, które bardzo dobrze znają, STUDENCI WYCOFANI - jak nazwa wskazuje są osobami wycofanymi, w każdej sytuacji stawiają na siebie - swoje uczucia, wiedzę i doświadczenia, mają niską samoocenę i wiarę w siebie, STUDENCI SKUTECZNI - są to osoby, u których „nowe” wywołuje pewien lęk, ale ten stan pobudza ich do działania, do poszukiwania rozwiązań, aby pokonać pojawiające się trudności, pomagają innym i sami z tej pomocy korzystają. Świadomość tego, którym typem studenta się utożsamia dana osoba lub z jakim typem do czynienia ma nauczyciel akademicki ułatwia rozwiązywanie pojawiających się dylematów. Autorzy publikacji Trudności doświadczane przez studentów..., dokonali przeglądu badań naukowych (m.in. Kramer i Hoffmann, Splangler, Zimbardo, Johson i McCann, Rostowskiej, Ogińskiej-Bulik) i wyodrębnili, iż do trudności, z którymi studenci borykają się najczęściej, należą ilość materiału, jaki muszą opanować oraz brak jego zrozumienia, rozłąka z najbliższymi, wymagania stawiane przez nauczycieli akademickich oraz instrumentalne traktowanie, nieznane środowisko, sytuacja materialno-bytowa, konieczność usamodzielnienia się, presja ze strony bliskich, dysonans miedzy wartościami panującymi w rodzinie generacyjnej a nowopoznanym środowiskiem. Rozdział ten został wzbogacony o autentyczne wypowiedzi wykładowców i studentów w ramce zatytułowanej $Z$ doświadczeń nauczyciela akademickiego, co przyczynia się do lepszego zrozumienia przedstawianych treści. Teoria ukazywana jest w świecie empirii.

4 J. Iskra, Sposoby radzenia sobie z trudnościami przez studentów, Wydawnictwo Difin, Warszawa 2015, [w:] J. Iskra, W. Klinkosz, Trudności doświadczane przez studentów..., dz. cyt., s. 27-30. 
Kolejna część nosząca tytuł Skąd się biora trudności i co z nimi zrobić stanowi pewnego rodzaju poradnik i informator. Autorzy skupili się na przedstawieniu „bagażu studenta oraz nauczyciela akademickiego”. Iskra i Klinkosz poprzez bagaż studenta rozumieją wszystkie czynniki zewnętrzne i wewnętrze, które wpłynęły na ukształtowanie się osobowości danej jednostki i obrazu samego siebie. Jak pisał Maslow, posiadanie obrazu siebie samego jest aspektem nieodzownym, gdyż „[...] człowiek dobrze przystosowany zna swoje prawdziwe motywy działań, odrzuca nieosiągalne dla siebie cele, potrafi umiejętnie współdziałać z innymi”" . Obraz siebie to umiejętność oceny i wyodrębnienia swoich mocnych i słabych stron. Umiejętność ujrzenie siebie samego, według autorów nie jest czymś, co człowiek osiąga od razu. Jest to proces, kształtuje się na bazie doświadczeń jednostki, czynników genetycznych, osobowych, jak i środowiskowych. Autorzy podkreślają także, że „poradzenie sobie z bagażem własnych uwarunkowań i doświadczeń, które wpływają na nasze życie i drogę, którą podążamy, nie jest ani łatwe, ani krótkotrwałe. Wymaga zaangażowania, pracy nad sobą, samodyscypliny i czasu" ". Jednakże, Iskra i Klinkosz dają kilkanaście propozycji, jak studenci (i nie tylko) mogą radzić sobie z trudnościami, jakie pojawiają się w ich życiu. Piszą między innymi o tym, aby zaprzestać narzekania na swój los, a zacząć działać, zaczynając od dobrych zmian, odnaleźć kontrolę nad samym sobą i nie oddawać jej nikomu, ani niczemu, otwierać się na zmiany, przestać zadowalać wszystkich dookoła, nie popełniać wciąż tych samych błędów, a także oczekiwania natychmiastowych rezultatów wszelkich działań - wielkie rzeczy są procesem. Odnosząc się do bagażu nauczyciela akademickiego, zadają pytanie dotyczące tego, kim jest łatwiej być studentem czy akademikiem? Piszą, że tak jak uzyskanie umiejętności zobrazowania samego siebie przez studenta jest procesem długim i niełatwym, tak też się dzieje z uzyskaniem statusu efektywnego akademika. Iskra i Klinkosz niejednokrotnie powtarzają, że relacja wykładowca - student, nie powinna przyjmować

5 A. H. Maslow, Motywacja i osobowość, PWN, Warszawa 1990, [w:] J. Iskra, W. Klinkosz, Trudności doświadczane przez studentów..., dz. cyt., s. 43.

6 J. Iskra, W. Klinkosz, Trudności doświadczane przez studentów..., dz. cyt., s. 48. 
postać autokraty i podwładnego, lecz partnerstwa. Nauczyciel akademicki nie może zapominać, że on także może nauczyć się wiele od swoich studentów, nawet podczas powszechnego dialogu.

Trudności doświadczane przez studentów to nazwa trzeciego rozdziału recenzowanej publikacji. W części tej autorzy przedstawiają rozwiązania metodologiczne, materiał empiryczny, jego analizę i wnioski końcowe. Badacze posłużyli się Jakościową Analizą Personalistyczną, która stanowi psychologiczną analizę zdarzeń życiowych opisanych przez osoby uczestniczące w badaniach. W arkuszu JAP wyróżnia się następujące zapisy jednostek a) temat zapisanego zdarzenia, b) źródłowe jednostki analizy oraz wyznaczniki ich odniesień i orientacji w wymiarach: biosferycznym, egzystencjalnym, dialogu osobowego, c) jednostki dopełniające sens przedmiotu doświadczenia w wymiarach: środowiskowym, subiektywnym, werbalnym. Każdy z elementów arkusza JAP został szczegółowo opisany przez autorów. Grupę badawczą stanowili studenci pierwszego roku studiów (którzy byli już po pierwszej sesji), kierunków humanistycznych i społecznych. Badania były anonimowe i dobrowolne, w badaniu wzięło udział 250 osób, z czego wybrano 25 opisów najbardziej typowych i pozbawionych elementów jakiejkolwiek identyfikacji. Zadaniem badanych było dokonanie opisu doświadczanych trudności związanych ze studiowaniem, uwzględniając co wydarzyło się przed, w trakcie i po danym wydarzeniu. Po przedstawieniu i przeanalizowaniu materiału empirycznego, Iskra i Klinkosz wysnuli miedzy innymi takie konkluzje. Trudności studentów wynikają między innymi z braku klarownych komunikatów dotyczących przebiegu zajęć, egzaminowania i oceniania przez wykładowców, nieumiejętność rozdzielenia życia prywatnego od życia zawodowego przez akademików, zawyżanie swoich możliwości przez studentów, brak umiejętności rozkładania nauki w czasie, poczucie osamotnienia. Badania przedstawiają niezwykle interesujące odpowiedzi. Konieczne byłoby zagłębienie się w nie i odnalezienie rozwiązań redukujących powyższe dylematy.

Ostatni rozdział - czwarty - nazwany został Kwestionariusz Trudności Studenckich (KTS) - metoda badania. W tej części Iskra i Klinkosz przedstawili procedury konstruowania autorskiego Kwestionariusza Trudności Studenckich. Każdy krok został szczegółowo opisany, z zachowaniem wszelkich czynności metodologicznych. Między inny- 
mi wyodrębniono najczęściej wskazywane przez studentów trudności, dokonano sprawdzenia rzetelności, stałości pomiaru, trafności, normalizacji kwestionariusza, wyodrębniono normy stenowe, dokonano charakterystyki skal oraz wyróżniono typy studentów. Autorzy wyróżnili skale takie jak emocjonalne reagowanie, wyalienowanie $\mathrm{w}$ relacjach, przeciążenie wymaganiami. Z ich klasyfikacji wyodrębnić można takie typy studentów, jak swobodni i skuteczni, radzący sobie, nie odnajdujący się oraz zniechęceni wymaganiami. Mocnym punktem tego rozdziału, jest przedstawienie przykładowego badania oraz interpretacja jego wyników. Iskra i Klinkosz zaznaczają, że niniejszy KTS jest metodą do badania trudności, jakie doświadczają młode osoby rozpoczynające studia na uczelniach wyższych, może być stosowany w badaniach indywidualnych i grupowych, adresowany dla psychologów i nauczycieli akademickich.

Na końcu książki zamieszczone zostały aneksy - jednostki analizy źródłowe i dopełniające sens przedmiotu doświadczania. Dodano także Kwestionariusz Trudności Studenckich gotowy do przeprowadzenia wśród studentów.

Recenzowana pozycja adresowana jest zarówno grona nauczycieli akademickich, samych studentów, jak i osób, które planują rozpocząć edukację na poziomie wyższym. Książka zawiera w sobie nie tylko treść merytoryczną, która została ukazana w oparciu o wiele badań naukowych, ale także część praktyczną. Ta sanowi efekt wieloletniej pracy autorów - Justyny Iskry oraz Waldemara Klinkosza. Wartością dodatnią pracy jest autorskie narzędzie stworzone przez badaczy z załączonym, szczegółowym opisem jego użytkowania. Dzięki Kwestionariuszowi Trudności Studenckich podjęta przez autorów tematyka, może być rozszerzana poprzez kolejne badania naukowców z wykorzystaniem tego narzędzia pomiaru. Książka ta może stać się także doskonałym elementem współpracy między nauczycielami akademickimi, jak i studentami. Mogą oni wspólnie opracowywać rekomendacje do zmniejszania lub nawet niwelowania trudności, z jakimi muszą sobie radzić studenci i nierzadko ma to także wpływ na pracę akademików. 